\title{
URGENSI PEMBENTUKAN BADAN PENYELESAIAN SENGKETA ANTARA KLUB SEPAK BOLA DAN PESEPAK BOLA PROFESIONAL DALAM RANGKA MENDUKUNG PEMBANGUNAN EKONOMI NASIONAL

\author{
(Urgency of The Establishment of Dispute Settlement Body Between Football Clubs and \\ Professional Football Players in Order to Support National Economic Development)
}

\author{
Eko Noer Kristiyanto \\ Badan Penelitian dan Pengembangan Hukum dan HAM \\ Kementerian Hukum dan HAM RI \\ Jalan HR. Rasuna Said Kav. C-1, Jakarta, Indonesia \\ Email: ekomaung69@gmail.com
}

Naskah diterima: 20 Februari 2018; revisi: 5 April 2018; disetujui: 17 April 2018

\begin{abstract}
Abstrak
Sepak bola profesional telah menjadi bisnis dan industri yang mendukung upaya kesejahteraan umum dalam konteks pembangunan ekonomi. Namun sengketa yang seringkali terjadi antara pemain dan klub membuat suasana tidak kondusif. $\mathrm{Hal}$ ini bisa berdampak pada minat investor yang ingin terlibat dalam industri sepak bola. Tulisan ini mencoba memberi gambaran tentang eksistensi lembaga yang berpotensi untuk mengatasi persoalan ini. Penelitian dilakukan dengan metode normatif yang diperkuat oleh hasil wawancara. Ternyata lembaga yang ada sekarang tidak relevan dan tidak efektif untuk menjadi solusi, perlu dibentuk lembaga arbitrase yang khusus menangani sengketa antara pemain dan klub. Tidak ada masalah dalam pembentukan lembaga ini, karena mendapat legitimasi dari komunitas sepak bola maupun negara.

Kata Kunci: sepak bola profesional, sengketa, arbitrase, komunitas
\end{abstract}

\begin{abstract}
Professional football has become a business and industry that supports the general welfare in the context of economic development. But the disputes that often occur between players and clubs make the atmosphere unconducive. This could have an impact on the interest of investors who want to get involved in the football industry. This paper tries to give an idea of the existence of potential institutions to solve this problem. The research was conducted by a normative method which was strengthened by intervies. It turns out that the existing institutions are irrelevant and ineffective to be a solution, it is necessary to establish an arbitration institution that specifically handles disputes between players and clubs. There is no problem in establishing this institution, as it gets the legitimacy of the football community as well as the country.
\end{abstract}

Keywords: professional football, disputes, arbitration, community 


\section{A. Pendahuluan}

Pembangunan ekonomi merupakan bagian penting dari pembangunan nasional, pembangunan ekonomi berkaitan erat dengan tujuan negara yang dinyatakan dalam konstitusi yaitu memajukan kesejahteraan umum. Undang-Undang Dasar Negara Republik Tahun 1945 disebut juga konstitusi ekonomi, salah satu ciri terpentingnya sebagai konstitusi ekonomi adalah bahwa UUD 1945 mengandung ide negara kesejahteraan (welfare state). ${ }^{1}$ Tujuan utama negara Indonesia yang dimuat dalam Undang-Undang Dasar Negara Republik Tahun 1945 adalah untuk memajukan kesejahteraan umum. Negara berkewajiban memajukan kesejahteraan umum (promoting public welfare) dan memaksimalkan kesejahteraan sosial (to maximize social welfare). ${ }^{2} \quad$ Negara berfungsi menciptakan syarat dan kondisi serta infrastruktur yang cukup untuk memperoleh kesejahteraannya. Pemerintah dibentuk bukan untuk menciptakan kesejahteraan umum, melainkan memajukan kesejahteraan umum. ${ }^{3}$ Kesejahteraan umum adalah hal yang terus diupayakan secara terus menerus dalam konteks perkembangan zaman, parameternya pun menyangkut banyak aspek namun tentu yang paling utama adalah aspek ekonomi.

Dalam konteks welfare state, negara berkewajiban menjamin ketersediaan akses menuju kesejahteraan bagi warga negaranya, upaya negara untuk mewujudkan kesejahteraan umum dilakukan mencakup berbagai bidang kehidupan dalam perspektif dan dimensi yang luas, termasuk di antaranya menjamin kegiatankegiatan yang merangsang geliat ekonomi masyarakat, termasuk di antaranya adalah kegiatan olah raga profesional, olah raga dalam konteks global semakin modern dan merambah sektor industri dan ekonomi, sekaligus menjadi salah sarana memajukan kesejahteraan umum melalui distribusi pendapatan dan determinasi ekonomi dari berbagai lapisan masyarakat melalui berbagai sektor.

Industri olah raga adalah industri yang berpotensi besar untuk menggerakkan perilaku ekonomi masyarakat secara kolektif. Dengan demikian industri olah raga berpotensi sebagai sektor yang dapat memberikan dampak signifikan bagi pengentasan kemiskinan dan penanggulangan pengangguran. Industri olah raga perlu digugah dan didukung melalui serangkaian kebijakan sistematis dari pemerintah pusat dan daerah, masyarakat, dan investor. $^{4}$

Kompetisi sepak bola profesional sebagai kompetisi yang melibatkan cabang olah raga yang paling digemari di seluruh dunia memberi sumbangsih dan kesempatan yang sangat besar bagi pemajuan kesejahteraan umum. ${ }^{5}$ Kompetisi sepak bola profesional menciptakan kesempatan kerja yang sangat besar bagi pemain

Muhammad Yamin, Naskah Persiapan Undang-Undang Dasar 1945 (Jakarta: Jajasan Prapantja, 1960), hlm.298, hal ini ditegaskan pula dalam pidato pengukuhan guru besar Prof. Jimly Asshiddiqie pada FH UI pada 13 Juni 1998.

2 Robert R Goodin, Responsibility Right \& Welfare, The Theory of the Welfare State (Colorado: Westview Press, 1988), hlm.22.

3 Pengertian tentang kesejahteraan umum dapat dilihat dari tingkat pendapatan suatu negara dan distribusi ekonomi di antara warga negara.

4 Agus Kristiyanto, "Penguatan Kebijakan Publik Usaha Pengentasan Kemiskinan Melalui Pengembangan Industri Mikro Olah Raga", Jurnal Ekonomi Pembangunan Volume 12, Nomor 2 (2011), hlm.211.

5 Hinca IP Pandjaitan, Kedaulatan Negara VS Kedaulatan FIFA (Jakarta: PT Gramedia Pustaka Utama, 2011), hlm.4 
sepak bola, pengelola sepak bola, pebisnis sepak bola, pengusaha kuliner, pengusaha konveksi, pengusaha transportasi, pengusaha media, pengusaha hotel, pengusaha infrastruktur, dan pelaku-pelaku ekonomi lainnya. ${ }^{6}$ Ada lebih dari 270 juta orang di dunia yang aktif dalam sepak bola, mencakup pemain dan perangkat sepak bola. Dari 85 Juta pemain yang aktif di sepak bola asia, ada sekitar 7.094 .000 pemain di Indonesia. ${ }^{7}$ Tekad dan komitmen mengarahkan sepak bola Indonesia ke arah industri ditegaskan dengan mewajibkan seluruh klub sepak bola peserta kompetisi profesional untuk berstatus badan hukum Perseroan Terbatas (PT) yang tujuan utamanya adalah laba. Klub dituntut untuk mandiri dan mengoptimalkan pendapatan dari lima aspek yaitu sponsorship, hak siar televisi, tiket pertandingan, merchandise, dan penjualan pemain. ${ }^{8}$ Melalui determinasinya kompetisi sepak bola profesional di Indonesia jelas memiliki pengaruh terhadap geliat ekonomi dan kesejahteraan masyarakat Indonesia. Kompetisi sepak bola profesional yang digulirkan mampu meningkatkan nilai pendapatan kotor Indonesia senilai 139 juta dolar Amerika Serikat (AS) atau sekitar 1,8 triliun rupiah. ${ }^{9}$

Namun ternyata dampak positif dalam penyelenggaraan sepak bola di Indonesia tidak diimbangi dengan instrumen dan kelembagaan untuk menyelesaikan konflik dan sengketa di antara pelaku sepak bola itu sendiri. Padahal ini penting untuk menjamin kepastian hukum dan perlindungan HAM bagi para pelaku sepak bola utamanya para pemain sepak bola. Memang betul Republik Indonesia telah memiliki sistem peradilan dan lembaga peradilan sendiri yang berada di bawah Mahkamah Agung. Namun statuta FIFA menyatakan bahwa segala macam konflik dan sengketa stakeholders tidak boleh dibawa ke pengadilan negara. Federasi Sepak bola Indonesia sebagai otoritas sepak bola tertinggi di Indonesia harus menjamin hal ini dilaksanakan jika tak ingin mendapat hukuman dari FIFA, karena FIFA memang tak menghendaki adanya intervensi negara dalam permasalahan yang dihadapi anggotanya. ${ }^{10}$ Namun di lain pihak PSSI (Persatuan Sepak Bola Seluruh Indonesia) selaku federasi ternyata

$6 \quad$ Eko Noer Kristiyanto, pengamat hukum olah raga mengatakan: "Tak dapat dipungkiri, sebagai permainan paling populer di dunia sepak bola telah menyentuh banyak aspek kehidupan, eksistensi sepak bola menjadi lebih dari sekedar sebuah olah raga ketika melihat keterkaitannya dengan dunia industri, tak hanya industri besar seperti penyiaran, otomotif, perbankan, penerbangan dll, namun juga industri kecil seperti konvenksi, marchendise dan kuliner rumahan. Terlebih geliat ekonomi yang terintegrasi dalam penyelenggaraan sepak bola itu sendiri, seperti nafkah bagi mereka yang berada di lingkaran football family (pemain, pelatih, official, wasit, hakim garis dll) , sponsorship, penjualan tiket pertandingan, media, hingga elemen yang terkadang dianggap remeh seperti penjual kaos emperan dan aktivitas perparkiran di stadion, semua dinamika ekonomi itu terjadi karena adanya pertandingan sepak bola.", Lihat Eko Noer Kristiyanto, “Sepak Bola dan Kesejahteraan Umum”, OPINI, HU tribun jabar 20 Agustus 2015.

7 Berdasar survei yang dilakukan FIFA, dapat dilihat dalam http://www.fifa.com/mm/document/fifafacts/ bcoffsurv/bigcount.staatpackage_7024.pdf, dalam Hinca IP Pandjaitan, Kedaulatan Negara VS Kedaulatan FIFA, (Jakarta: PT Gramedia Pustaka Utama, 2011), hlm.5.

$8 \quad$ Eko Noer Kristiyanto, Implementasi Peraturan Menteri Dalam Negeri Nomor 13 Tahun 2006 Tentang Pedoman Pengelolaan Keuangan Daerah Dalam Pengalokasian Dana APBD Kepada Klub Sepak Bola Peserta Liga Indonesia (Bandung: UNPAD, 2008).

9 Terungkap dalam jumpa pers yang dilakukan oleh PT.GTS selaku operator dari kompetisi TSC 2016 pada tanggal 29 Juni 2016, data tersebut didapatkan melalui kerjasama antara PT.GTS dan PricewaterhouseCoopers (PwC), perusahaan audit dan konsultan finansial asal London Inggris. Lihat HU TopSkor edisi Kamis 30 Juni 2016, hlm.15.

10 Pasal 13 dan 17 statuta FIFA 
tak menyediakan solusi bagi permasalahan dan sengketa yang terjadi khususnya antara pemain dan klub. Sudah menjadi hal lumrah jika klub sepak bola di Indonesia tak memenuhi hak-hak pemain terutama terkait pembayaran gaji. Ketika akan menuntut klub maka pemain seringkali kebingungan karena ketiadaan lembaga peradilan yang jelas. Permasalahan ini pun sebenarnya terjadi di luar negeri. ${ }^{11}$ Hanya saja di negara yang sepak bolanya maju seringkali masalah bisa tuntas karena ada lembaga penyelesaian sengketa yang jelas.

Awal tahun 2017 menjadi momentum penting bagi sepak bola Indonesia, karena akan dicanangkan pembentukan NDRC (National Dispute Resolution Chamber). Lembaga ini kelak akan menangani dan menyelesaikan sengketa yang terjadi antara pemain dan klub sepak bola di Indonesia. Dalam tugas mereka nanti, NDRC bertindak berdasarkan aduan. Bentuk badan ini layaknya pengadilan arbitrase, tetapi khusus sepak bola dan bersifat independen, meski berada dalam naungan PSSI. Ada tiga substansi sengketa yang dapat diselesaikan di badan ini, yaitu terkait dengan kontrak pemain di klub, kompensasi latihan (training compensation), atau kompensasi yang diberikan klub ketika mengikat kontrak pemain secara profesional kepada klub tempat pesepak bola dilatih saat masih berstatus amatir di usia muda, serta kompensasi solidaritas, yaitu mekanisme penghargaan transfer antarklub. ${ }^{12}$ FIFA juga memberi bantuan kepada PSSI untuk pembentukan NDRC ini senilai 40 ribu dolar AS. ${ }^{13}$

Pembentukan lembaga untuk menyelesaikan sengketa di dunia sepak bola ini tentu sangat penting mengingat begitu banyak persoalan yang terus berulang dan itu semua terkait dengan hukum serta hak individu. Lalu sejauh apa urgensi pembentukan lembaga ini mengingat Indonesia pun mengakui eksistensi lembaga-lembaga peradilan dan arbitrase termasuk arbitrase olah raga?

\section{B. Metode Penelitian}

Metode penelitian yang digunakan dalam penulisan ini adalah metode penelitian hukum normatif, metode penelitian hukum normatif pada dasarnya meneliti kaidah-kaidah hukum dan asas-asas hukum ${ }^{14}$, penelitian normatif akan mencoba menemukan suatu aturan hukum, prinsip hukum, maupun doktrin hukum guna menjawab isu hukum yang dihadapi ${ }^{15}$, khususnya terkait teori-teori tentang pluralisme hukum dan mekanisme penyelesaian sengketa di luar peradilan juga hubungannya dengan eksistensi hukum nasional yang berlaku. Juga menjelaskan

11 Nyon, "Klub Tak Bayar Gaji Pemain Ada Juga di Eropa", detikSport, https://sport.detik.com/sepakbola/boladunia/2296988/klub-tak-bayar-gaji-pemain-juga-ada-di-eropa, diakses 11 Januari 2018.

12 Satria Sakti Utama, "Sengketa Sepak Bola Kini Ditangani NRDC", Media Indonesia, http://www.mediaindonesia. com/news/read/140721/sengketa-sepak-bola-kini-ditangani-ndrc/2018-01-15, (diakses 15 Februari 2018).

13 PSSI, "Hasil Pertemuan FIFA dengan PSSI Terkait NDRC", http://www.pssi.org/news/hasil-pertemuan-fifadengan-pssi-terkait-ndrc, PSSI, diakses 11 Januari 2018.

14 Bagir Manan, "Penelitian Terapan di Bidang Hukum", (disampaikan pada Lokakarya Peranan Naskah Akademis Dalam Penyusunan Peraturan Perundang-undangan, BPHN, Jakarta, 9 - 11 November 1993), hlm.7. Soerjono Soekanto dan Sri Mamudji menyatakan bahwa penelitian hukum normatif atau penelitian hukum kepustakaan merupakan penelitian hukum yang dilakukan dengan cara meneliti bahan pustaka atau data sekunder belaka yaitu dengan cara menelaah permasalahan dengan berpedoman pada data sekunder lihat Soekanto, Soerjono dan Sri Mamudji, Penelitian Hukum Normatif: Suatu Tinjauan Singkat (Jakarta: Raja Grafindo Persada, 2001).

15 Peter Mahmud Marzuki, Penelitian Hukum (Jakarta: Kencana, 2010), hlm. 35. 
bagaimana suatu penyelenggaraan kompetisi sepak bola profesional ternyata berkontribusi positif terhadap salah satu tujuan negara yang dinyatakan dalam konstitusi yaitu memajukan kesejahteraan umum dan berdampak pada pembangunan ekonomi nasional. Penelitian ini menelaah permasalahan dengan berpedoman pada data sekunder yang dilakukan dengan studi pustaka terhadap bahan-bahan hukum dan bahan non-hukum yang berkaitan dengan judul penelitian. Bahan hukum sekunder yang dimaksud adalah doktrin, ajaran para ahli, hasil karya ilmiah para ahli, berita-berita dan hasil wawancara pihak terkait yang diperoleh dari surat kabar serta situs-situs internet yang relevan dengan judul penelitian.

Data di atas dikumpulkan melalui studi kepustakaan (library research), penelurusan melalui media internet (online research), dalam hal ini penulis menitikberatkan dalam konteks jaminan hukum dan penyelesaian sengketa akan menjamin pula kualitas kompetisi sepak bola dalam rangka memajukan kesejahteraan umum yang berdampak pula terhadap pembangunan ekonomi nasional.

\section{Pembahasan}

\section{Sengketa Antara Pemain dan Klub}

Jika timbul sengketa dalam konteks
formiil biasanya orang memilih untuk

menyelesaikannya di jalur pengadilan ataupun luar pengadilan seperti arbitrase sebagai forum alternatif. ${ }^{16}$ Munculnya sengketa jika salah satu pihak menghendaki pihak lain untuk berbuat atau tidak berbuat sesuatu tetapi pihak lainnya menolak berlaku demikian. Pencarian berbagai jenis proses dan metode untuk menyelesaikan sengketa yang muncul adalah sesuatu yang urgen dalam masyarakat. Para ahli non hukum banyak mengeluarkan energi dan inovasi untuk mengekspresikan berbagai model penyelesaian sengketa (dispute resolution). Berbagai model penyelesaian sengketa, baik formal maupun informal, dapat dijadikan acuan untuk menjawab sengketa yang mungkin timbul asalkan hal itu membawa keadilan dan kemaslahatan. ${ }^{17}$ Statuta FIFA yang tak menghendaki terlibatnya negara termasuk organ yudisial membuat arbitrase menjadi pilihan paling logis bagi para pihak untuk menyelesaikan sengketa, pelembagaan arbitrase sudah sangat baik di negara-negara yang sepak bolanya sudah maju. Hal ini disebabkan banyak faktor, termasuk industrialisasi sepak bola yang membuat kepastian hukum menjadi penting serta tingkat edukasi yang baik termasuk kesadaran dan pemahaman hukum.

Bicara hubungan tentang hak dan kewajiban antara pemain dan klub maka akan selalu terkait dengan kontrak. ${ }^{18}$ Masalah tunggakan

16 Yansen Darmanto Latip, Pilihan Hukum dan Pilihan Forum Dalam Kontrak Internasional (Jakarta: UI, 2002) hlm. 243.

17 Ibid.

18 Jika bicara kontrak, maka tidak dapat terlepas dari hukum perdata. Kontrak merupakan bentuk lain dari perjanjian yang menurut Prof. Subekti, adalah suatu peristiwa dimana seorang berjanji kepada seorang lain atau dimana kedua orang itu saling berjanji untuk melaksanakan sesuatu hal. Dalam hal ini, kontrak pemain adalah perjanjian antara pihak klub dengan pemain sepak bola, tuk melaksanakan sesuatu hal yang apalagi kalau bukan bermain sepak bola. Setiap perjanjian yang dibuat oleh para pihak akan menimbulkan akibat hukum. Akibat hukum itu sendiri adalah timbulnya hak dan kewajiban. Jika pemain berkewajiban bermain di dalam pertandingan resmi klub, maka kewajiban klub adalah membayar si pemain. Dalam ilmu hukum perdata, kewajiban yang tidak dijalankan atau dipenuhi adalah wanprestasi (ingkar janji). Kondisi itu yang akan menjadi sengketa dan harus diselesaikan oleh para pihak yang terlibat di dalam kontrak. 
gaji hanyalah satu dari sekian banyak masalah yang mungkin terjadi. Selama itu diatur di dalam kontrak, maka para pihak yang terlibat dalam hal ini pihak klub dan pihak pemain, adalah subjek utama di dalam sengketa. Itulah mengapa, kontrak yang baik adalah yang turut memuat mekanisme penyelesaian sengketa. Berdasarkan kontrak yang umum dibuat oleh para pemain bola di Indonesia, diketahui bahwa sengketa yang terjadi wajib diselesaikan secara kekeluargaan. Jika dengan cara kekeluargaan masih belum beres, maka tahap selanjutnya adalah penyelesaian melalui "prosedur keluhan" sebagaimana tertuang pada kontrak di atas. Adapun prosedur tersebut dapat dimaknai sebagai keterlibatan PSSI selaku pihak ketiga di dalam kontrak pemain. ${ }^{19}$ Dalam ketentuan Pasal 1317 KUHPerdata, kedua pihak yang telah bersepakat dapat pula mengadakan perjanjian untuk melibatkan pihak ketiga. Hal ini sesuai dengan semangat hukum perjanjian yang menganut sistem terbuka. Artinya, hukum perjanjian memberikan kebebasan seluasluasnya kepada masyarakat tuk mengadakan perjanjian yang berisi apa saja, sepanjang tak bertentangan dengan ketertiban umum dan kesusilaan.

Dalam hal melibatkan federasi sepak bola di dalam kontrak pemain, hal ini masuk akal dan tentu saja sama sekali tidak bertentangan dengan ketertiban umum apalagi kesusilaan. Pasal 4 ayat (1) butir d Statuta PSSI menyatakan bahwa PSSI bertujuan untuk melindungi Anggota. Adapun yang dimaksud "anggota" dalam hal ini adalah klub-klub yang menjadi peserta di kompetisi yang diselenggarakan PSSI. Sehingga, penting bagi PSSI untuk memberi perlindungan bagi klub pada setiap aktivitasnya termasuk yang tertuang di dalam kontrak pemain. ${ }^{20}$ Dalam rangka melindungi para anggotanya, PSSI juga membentuk suatu badan peradilan melalui Pasal 69 Statuta PSSI yang menangani semua perselisihan internal nasional antara PSSI, anggota-angotanya, pemain-pemain, petugas dan pertandingan serta agen pemain yang tidak berada di bawah kewenangan badan-badan hukumnya. ${ }^{21}$ Tentu saja peradilan itu harus berada di luar peradilan umum yang dikuasai Negara. ${ }^{22}$

\section{Kasus Bambang Pamungkas}

Sebagai anggota PSSI, wajar apabila klub mendapat perlindungan dari federasi. Namun pemain seringkali tak mendapat perlindungan dan pendampingan yang layak saat berhadapan dengan klubnya. Persoalan inilah yang mendorong dibentuknya Asosiasi Pemain Sepakbola Profesional Indonesia (APPI). ${ }^{23}$ Dalam riwayatnya, APPI sudah sering mengadvokasikan kasus-kasus yang menimpa

19 Agung Putranto Wibowo, “Penyelesaian Sengketa Kontrak Pemain: Kewenangan Para Pihak", Kumparan, https:// kumparan.com/agung-putranto-wibowo/penyelesaian-sengketa-kontrak-pemain-kewenangan-para-pihak, diakses 11 Januari 2018.

20 Agung Putranto Wibowo , Op.cit.

21 Agung Putranto Wibowo, Op.cit.

22 Awal tahun 2017, PSSI menerima injeksi dana sebesar USD 40 ribu dari FIFA. Adapun uang itu dimandatkan untuk membentuk National Dispute Resolution Chamber (NDRC). NDRC ini nantinya berfungsi sebagai badan arbitrase dengan basis sengketa yang dibahas yakni kontrak klub dan pemain. FIFA menambahkan, agar nantinya lembaga ini diisi oleh berbagai unsur perwakilan, baik itu dari pemain, perwakilan klub, dan perwakilan PSSI.

23 APPI memiliki misi untuk melindungi, meningkatkan, dan menegosiasikan kondisi, hak dan status dari semua pemain profesional yang bermain dan berkontrak di Indonesia. 
pemain profesional. Contoh yang paling terkenal adalah ketika APPI mendampingi Bambang Pamungkas dan Leo Saputra menggugat PT Persija Jaya Jakarta ke Pengadilan Negeri Jakarta Pusat pada tahun 2013. setelah merasa diabaikan manajemen klub Persija terkait pelunasan gaji yang tertunggak. Dalam rilis yang disampaikan asosiasi pesepakbola profesional Indonesia (APPI), gugatan tersebut dilayangkan dan didaftarkan ke kepaniteraan Perdata Pengadilan Negeri Jakarta Pusat dengan nomor gugatan: 523/PDT.G/2013/PN.JKT.PST dan 522/ PDT.G/2013/PN.JKT.PST.

Gugatan yang diserahkan tim bantuan hukum APPI ini terpaksa dilayangkan, karena tidak ditemukannya penyelesaian permasalahan pembayaran kewajiban terhadap kedua pesepakbola tersebut oleh PT Persija Jaya Jakarta melalui jalur negosiasi. Ketika itu Persija telah lebih dari satu tahun memiliki tunggakan gaji terhadap sejumlah pemain selama beberapa bulan. Berbagai jalur komunikasi dan musyawarah telah ditempuh kedua pesepakbola tersebut bersama dengan APPI, dan manajemen klub hanya bisa memberikan janji tanpa membuahkan hasil yang diharapkan. Akibatnya, Bambang dan Leo menempuh jalur hukum. ${ }^{24}$ Apa yang dilakukan oleh Bambang Pamungkas ini adalah suatu terobosan, karena cara kekeluargaan dan negosiasi yang diperintahkan federasi ternyata tak membuahkan hasil. Memang benar statuta FIFA dan PSSI melarang sengketa dibawa ke pengadilan negara, namun di lain pihak PSSI pun tak memiliki solusi untuk menyelesaikan persoalan karena 3 organ yudisial yang dimiliki PSSI tidak memiliki kewenangan terkait persoalan ini. ${ }^{25}$ Langkah yang ditempuh oleh Bambang Pamungkas ini dijamin oleh hukum nasional Indonesia yang menyatakan bahwa pengadilan tak boleh menolak perkara yang masuk dengan alasan tak memiliki kewenangan mengadilinya. ${ }^{26}$ Pengadilan adalah sarana untuk mengupayakan hukum, tempat perlindungan hukum, sekaligus tempat mencari keadilan bagi warga negara yang tersangkut suatu sengketa. ${ }^{27}$

Langkah yang ditempuh oleh Bambang Pamungkas diharapkan mampu menghasilkan preseden untuk kasus-kasus serupa. Namun ternyata kasus ini berakhir damai sebelum adanya putusan. Klub Persija Jakarta dan Bambang Pamungkas akhirnya sepakat menyelesaikan sengketa dengan jalan damai. Persija bersedia memenuhi tuntutan Bambang Pamungkas, dan Bambang pun mencabut berkas gugatan hukum di Pengadilan Negeri Jakarta Pusat. ${ }^{28}$ Kasus Bambang Pamungkas adalah suatu perkecualian, nama besar dan relasinya dapat membuatnya melakukan perlawanan terhadap klub, padahal untuk kasus-kasus serupa di Indonesia hampir dapat dipastikan

24 Donny Afroni, "Bambang Pamungkas dan Leo Saputra Gugat Persija Jakarta”, Goal, http://www.goal.com/id/ news/1387/nasional/2013/11/19/4418163/bambang-pamungkas-leo-saputra-gugat-persija-jakarta, diakses 11 Januari 2018.

25 Tiga organ yang dimaksud adalah Komisi Disiplin, Komisi Banding, dan Komisi Etik, Ketiganya hanya menegakkan aturan terkait sepak bola, baca: Eko Noer Kristianto, "PSSI dan Organ Yudisialnya", Pikiran Rakyat, http://www. pikiran-rakyat.com/kolom/2017/08/13/pssi-dan-organ-yudisialnya-407254, diakses 11 Januari 2018.

26 Pasal 10 Undang-Undang Nomor 48 Tahun 2009 tentang Kekuasaan Kehakiman.

27 Rusli Muhammad, Kemandirian Pengadilan Indonesia (Yogyakarta: FH UII Press, 2009) hlm. 13.

28 Eko Noer Kristiyanto, “Bambang Pamungkas dan Bobotoh", Pikiran Rakyat, http://www.pikiran-rakyat.com/ kolom/2017/10/29/bambang-pamungkas-dan-bobotoh-persib-412469, diakses 11 Januari 2018. 
bahwa pemain takkan memiliki upaya karena daya tawar yang rendah. ${ }^{29}$

Dalam konteks internasional perseteruan antara pemain dan klub yang menghasilkan hukum yang diterima luas adalah tentang Aturan Bosman (Bosman ruling). Jean Marc Bosman bukanlah pemain hebat ataupun memiliki karir istimewa, namun dia telah melakukan sebuah revolusi dalam sepakbola. Langkah hukumnya telah mengubah struktur transfer pemain secara radikal. Saat itu (menjelang akhir 80an) Bosman ingin hengkang dari klub lamanya di Belgia, namun ketika itu tidak dikenal status free transfer, sehingga seorang pemain yang ingin pindah klub nasibnya tetap bergantung kepada klub walau masa kontraknya telah habis. Kemudian Bosman melakukan langkah hukum dengan menggugat klubnya ini ke pengadilan. Setelah melalui proses yang cukup panjang, puncaknya adalah pada tahun 1995 ketika mahkamah Uni Eropa memenangkan gugatannya, maka sejak itu pula setiap pemain yang telah habis kontraknya berhak menentukan masa depannya sendiri.

Setelah kejadian-kejadian tersebut, FIFA dan federasi di setiap negara sangat menghindari persinggungan dengan sistem peradilan negara karena memang sepak bola memiliki lembaga yudisialnya sendiri untuk memutus seluruh sengketa stakeholders. Oleh karena itu penyelesaian sengketa di luar pengadilan seperti negosiasi dan arbitrase selalu menjadi prioritas dan berkembang pesat di negara-negara yang sepak bolanya maju. Momentum bagi Indonesia hadir ketika FIFA mendukung pembentukan National Dispute Resolution Chamber (NDRC), ini dianggap solusi logis karena federasi belum memiliki lembaga dengan karakteristik NDRC namun di lain pihak federasi tak menghendaki turut campurnya pengadilan negara dalam sengketa klub dan pemain sepak bola.

\section{Arbitrase Olah Raga}

Dunia kini telah menjadi sangat global, komunitas-komunitas memiliki peranan dan kedaulatannya sendiri. Menurut Jimly Asshiddiqie dalam sistem demokrasi modern dewasa ini, sistem kekuasaan dalam kehidupan bernegara dapat dibedakan dalam tiga wilayah atau domain, yaitu negara (state), pasar (market), dan masyarakat (civil society). Ketiga wilayah atau domain kekuasaan itu memiliki logika dan hukum tersendiri. ${ }^{30}$ Inilah yang disebut Jimly sebagai teori organizational imperatives. Teori organizational imperatives ini berkaitan erat dengan teori kedaulatan pluralis, teori kedaulatan pluralis menyatakan bahwa kedaulatan itu tak selalu harus diartikan absolut dan menjadi milik negara semata. Kedaulatan dapat didesentralisasikan kepada komunitas masyarakat yang mampu melakukannya untuk memajukan kesejahteraan umum tanpa harus menciderai kedaulatan itu sendiri. ${ }^{31}$ Asumsi lain yang mendasari adalah pendapat bahwa setiap individu menjadi anggota satu

Eko Noer Kristiyanto, “Bambang Pamungkas dan Bobotoh", Pikiran Rakyat, http://www.pikiran-rakyat.com/ kolom/2017/10/29/bambang-pamungkas-dan-bobotoh-persib-412469, diakses 11 Januari 2018.

30 Jimly Asshiddiqie, Kemerdekaan Berserikat Pembubaran Partai Politik dan Mahkamah Konstitusi (Jakarta: Konstitusi Press, 2005), hlm. 43.

31 Para penganut teori hukum pluralis ini diantaranya adalah: Andrew Vincent dalam bukunya The theories of the state, juga HJ. Laski yang menulis buku Authority in the modern state, juga Prof. Jimly Asshiddiqie yang mengisyaratkan hal tersebut dalam bukunya Kemerdekaan Berserikat Pembubaran Partai Politik dan Mahkamah Konstitusi, serta menyatakan hal yang sama dalam acara Seminar Pembangunan Hukum Nasional 
atau lebih kelompok sosial atau kekuatan sosial tertentu sesuai dengan aspirasi dan kepentingannya, baik secara kultural, ideologis, maupun profesi, termasuk aspirasi ekonomi. Kelompok dan kekuatan sosial ini akan berjuang demi kepentingan anggotanya dan berupaya mempertahankan karakteristik dan otonominya baik dari pengaruh organisasi lain maupun dari campur tangan pemerintah. ${ }^{32}$

Permasalahan yang dihadapi pun menjadi sangat kompleks serta terus berkembang dan membutuhkan orang-orang yang ahli, khusus, spesial untuk memahami dan menemukan solusi jika menemukan masalah, termasuk masalah-masalah dalam komunitas olah-raga. ${ }^{33}$ Pengadilan konvensional yang memiliki hakim dengan kemampuan dan pemahaman sangat umum tidak dijadikan rujukan jika komunitas olah raga mengalami sengketa. Kita dapat menciptakan sistem pengklasifikasian dari sengketa dan sarana penyelesaiannya. ${ }^{34}$ Kita juga dapat melihat beberapa mekanisme atau sarana penyelesaian sengketa lebih cocok untuk jenis sengketa tertentu dibandingkan dengan jenis dan sarana sengketa yang lainnya. ${ }^{35}$ Idealnya kita dapat menciptakan suatu sistem yang mempertimbangkan, baik kepentingan pribadi maupun kepentingan umum dalam penyelesaian sengketa. ${ }^{36}$ Dalam Dunia Olahraga, arbitrase dikenal sebagai mekanisme umum untuk menyelesaikan permasalahan dan sengketa yang melibatkan para atlet, dikenal apa yang dinamakan Court of Arbitration for Sport) CAS.

\section{a. Court of Arbitration for Sport) CAS}

Teori Kedaulatan pluralis melahirkan pluralisme hukum, yaitu kehadiran sistem hukum transnasional selain sistem hukum nasional dan sistem hukum internasional. Hukum transnasional adalah hukum yang terbentuk oleh komunitas internasional yang bukan negara (international society) dan berlaku bagi komunitasnya melintasi batas-batas wilayah negara secara administratif. Pandangan pluralisme kedaulatan dan pluralisme hukum merupakan kritik terhadap pandangan kedaulatan absolut sekaligus kritik terhadap pandangan monisme, karena eksistensi suatu sistem hukum yang berasal dari sumber lain selain negara adalah suatu realitas. ${ }^{37}$ Pandangan hukum pluralisme mengakui bahwa setiap komunitas masyarakat atau grup sosial yang terorganisir juga memiliki sistem dan tata hukum yang sesuai dengan kebutuhannya dan bersifat otonom. Dalam konteks globalisasi seperti sekarang maka teori kedaulatan yang relevan bukanlah teori kedaulatan absolut akan tetapi teori kedaulatan pluralis dimana negara bukanlah satu-satunya pemegang peranan

yang diselenggarakan oleh BPHN-Kementerian Hukum dan HAM pada bulan Oktober 2016, Jimly mengatakan bahwa teori Montesque tentang pemisahan kekuasaan antara legislatif-eksekutif-yudikatif sebenarnya sudah tidak relevan karena perkembangan zaman, karena pilar penentu dan pemegang kedaulatan dalam bernegara saat ini adalah state, civil society, market + media.

32 Ramlan Surbakti, Memahami Ilmu Politik (Jakarta: PT Gramedia Widiasarana Indonesia, 2015), hlm. 97-98.

33 Terungkap di FGD tentang Sistem Peradilan di Indonesia yang diselenggarakan oleh Pusat Analisis dan Evaluasi Hukum BPHN-Kementerian Hukum dan HAM RI.

34 Rachmadi Usman, Pilihan Penyelesaian Sengketa di Luar Pengadilan, (Bandung: PT Citra Aditya Bakti, 2013).

35 Ibid.

36 Ibid.

37 Franck Latty, la lex sportiva, Boston 2007, dalam Hinca IP Pandjaitan, "Kedaulatan Negara VS Kedaulatan FIFA", (Jakarta: PT Gramedia Pustaka Utama, 2011), hlm.4 
penting dalam menjalankan dinamika negara, prinsipnya adalah pelaksanaan kedaulatan dapat didesentralisasikan kepada society.

Federasi-federasi olahraga internasional juga mengklaim otonomi untuk metode yang digunakan dalam menyelesaikan sengketa. Selalu diupayakan untuk memiliki yurisdiksi eksklusif dan mencegah atlet untuk mengakses pengadilan negara. Federasi olahraga internasional melakukan hal ini dengan beragam cara. Salah satunya adalah dengan menyatakan di dalam rulebook atau statutanya bahwa keputusan yang diambil adalah bersifat "final dan mengikat" dan karenanya atlet tidak berhak atas banding final ke pengadilan. Ketentuan ini dapat disebut sebagai "klausul pengecualian" di bidang olahraga. Cara yang kedua adalah dengan cara mewajibkan semua stakeholder olahraga untuk sengketa yang timbul hanya dapat dibawa ke arbitrase yang khusus dibuat dan dinyatakan tunduk untuk itu. Panel arbitrase ini berupa badan banding "independen" yang dibentuk oleh federasi olahraga internasional atau CAS (Court of Arbitration for Sport). Cara ketiga adalah atlet diminta menandatangani perjanjian untuk tidak melakukan tindakan hukum terhadap federasi-federasi olahraga internasional sebagai prasyarat untuk ikut serta dalam pertandingan internasional. Maksud dari taktik tersebut adalah untuk menciptakan zona pengadilan khusus dalam bidang regulasi olahraga, yang mengecualikan pengawasan judisial terhadap, atau intervensi dengan, pengambil keputusan. Aturan ini melarang para atlet mengakses pengadilan negara dan membiarkannya tergantung pada pengadilan arbiter federasifederasi olahraga internasionalnya. Federasi olahraga internasional dapat mengklaim bahwa pengadilan yang dimaksudkan hanya berasal dari panel arbitrase yang diciptakan dan ditunjuk oleh federasi olahraga internasional sendiri, atau paling jauh CAS.

Sejak didirikan sebagai perpanjangan tangan dari IOC (International Olympic Committe) pada tahun 1984, CAS telah berkembang menjadi otoritas yang dihormati dalam penyelesaian sengketa yang berhubungan dengan berbagai macam olahraga dan mengeluarkan berbagai macam yurisprudensi dalam penyelesaian sengketa tersebut. Tidak seperti pengadilan sipil tradisional, CAS memperoleh yurisdiksinya dalam kasus tertentu hanya melalui kesepakatan bersama dari pihak yang terlibat. Prosedur ini, yang dikenal sebagai arbitrase, dirancang untuk mengikat semua pihak. Dalam pelaksanaan tugasnya, CAS dapat menjadi sumber kategori baru norma-norma yang menggabungkan peraturan-peraturan yang sesuai untuk kompetisi-kompetisi dan prinsip-prinsip dasar hukum. Norma-norma tersebut yang berlaku terhadap seluruh komunitas olahraga dan, pada pokoknya terhadap kelompok-kelompok olahraga internasional, patut menyandang nama Lex Sportiva. ${ }^{38}$ Penggunaan arbitrase memungkinkan untuk mengangkat prinsipprinsip umum yang sesuai dengan kebutuhankebutuhan kepentingan yang hendak diatur oleh prinsip-prinsip tersebut. Prinsip-prinsip ini bersifat otonom dalam arti bahwa prinsip- 
prinsip tersebut tidak ditarik dari suatu sistem hukum negara dimana situasi sengketa dibatasi. $^{39}$

\section{b. Arbitrase Olah Raga di Indonesia}

Eksistensi lembaga arbitrase khusus olahraga pun dikenal di Indonesia, namun ternyata dianggap kurang efektif dan efisien sehingga membuat banyak pihak enggan membawa permasalahan ke arbitrase olah raga di Indonesia. ${ }^{40}$ Indonesia memang dikenal dua lembaga penyelesaian sengketa atau arbitrase olahraga, yakni Badan Arbitrase Keolahragaan Indonesia (BAKI) dan Badan Arbitrase Olahraga Indonesia (BAORI). BAKI dibentuk oleh Komite Olahraga Indonesia (untuk cabang-cabang yang dipertandingkan dalam olimpiade $)^{41}$, sedangkan BAORI dibentuk melalui KONI. ${ }^{42}$

Saat ini BAKI adalah lembaga arbitrase yang berafiliasi langsung ke Court of Arbitration for Sport (CAS), sebuah lembaga arbitrase internasional yang dibentuk oleh Komite Olimpiade Internasional atau dunia olahraga lebih mengenal CAS dengan istilah Supreme Court of World Sport, dengan kata lain BAKI adalah counterpart CAS di Indonesia. ${ }^{43}$

BAKI telah memiliki 2 (dua) perwakilan yang ditunjuk dan diakui oleh CAS untuk menjadi arbiterdiCAS. KeberadaanBAKI di Indonesiatidak berjalan sendiri ternyata BAORI juga memiliki kewenangan sebagai arbitase di Indonesia yang sama dengan BAKI namun apabila dilihat dari "mekanisme" pertanggungjawabannya, BAKI berafiliasi ke CAS sedangkan BAORI ke Komite Nasional Olahraga Indonesia (KONI).

Keberadaan BAORI di Indonesia memang tidak ideal, sebagai contoh misalkan ada pihak yang kurang puas dengan hasil keputusan BAORI maka untuk mengajukan tingkat berikutnya akan mengalami kesulitan dalam menentukan lembaga bandingnya, berbeda dengan BAKI yang mengakomodir pihak banding untuk dapat ditujukan ke CAS. ${ }^{44}$ Kelembagaan yang ada saat ini dianggap belum mampu mengakomodir penyelesaian sengketa yang kerap terjadi di cabang olah raga sepak bola profesional karena komposisinya pun tak mencerminkan stakeholders sepak bola. Masih diperlukan pembentukan lembaga yang lebih khusus lagi agar para pihak yang bersengketa segera mendapat solusi dan kepastian.

\section{Kepastian hukum dan Pembangunan Ekonomi Nasional}

Faktor yang utama bagi hukum untuk dapat berperan dalam pembangunan ekonomi adalah apakah hukum mampu menciptakan "stability", "predictability" dan "fairness". 45 Oleh karena

39 Franck Letty, Op. Cit

40 Riza Hufaida bagian legal APPI mengatakan bahwa lembaga arbitrase yang ada dianggap bukan solusi, karena adanya dualisme, juga biaya yang tinggi serta ketidakjelasan perangkat sidang saat melakukan persidangan.

41 Komite Olimpiade Indonesia (KOI) resmi membentuk Badan Arbitrase Keolahragaan Indonesia (BAKI) sesuai dengan Rapat Anggota KOI 2012 No. Kep.08/RA-KOI/I/2012.

42 Ali, "Dualisme Arbitrase Olahraga Indonesia Harus Diakhiri", Hukum Online, http://www.hukumonline.com/ berita/baca/lt52948f516fcf8/dualisme-arbitrase-olahraga-indonesia-harus-diakhiri, diakses 11 Januari 2018.

43 Rahmat Sulistiyo, "Berkenalan dengan NDRC, Calon Lembaga Arbitrase PSSI", Pandit Football, http://www. panditfootball.com/pandit-sharing/210079/PSH/170929/berkenalan-dengan-ndrc-calon-lembaga-arbitrasepssi, diakses 11 Januari 2018.

44 Ibid.

45 Erman Rajagukguk, "Peranan Hukum di Indonesia: Menjaga Persatuan, Memulihkan Ekonomi dan Memperluas Kesejahteraan Sosial”, (makalah disampaikan dalam rangka Dies Natalies dan Peringatan Tahun Emas Universitas Indonesia Jakarta: UI, 2000) 
itu maka hukum seharusnya berperan dalam pembangunan ekonomi, hukum haruslah menjadi pandu dan acuan dalam pembangunan. Termasuk dalam penyelenggaraan kompetisi sepak bola profesional yang mendukung pemajuan kesejahteraan umum. Dalam konsep welfare state, tugas pemerintahan dalam negara hukum tidak saja untuk menjalankan pemerintahan, tetapi lebih dari itu harus meningkatkan kesejahteraan masyarakat dalam rangka mencapai tujuan negara. ${ }^{46}$ Upaya tersebut dilakukan melalui pembangunan nasional yang bersifat multi komplek. ${ }^{47}$ Olah raga dalam konteks global semakin modern dan tak sekedar menjadi aktivitas terkait kesehatan semata namun juga industri dan ekonomi, sekaligus menjadi salah satu faktor atau sarana untuk memajukan kesejahteraan umum melalui distribusi pendapatan di tingkat grassroot sampai di tingkat elit.

Pembangunan nasional secara keseluruhan melibatkan juga pembangunan hukum, tujuan pembangunan hukum adalah juga menjadi tujuan penegakkan hukum. ${ }^{48}$ Roscoe Pound mengembangkan tiga golongan yang harus dilindungi oleh hukum yaitu kepentingan umum, sosial, dan perorangan. Dalam masyarakat beradab, orang mengasumsikan bahwa orang yang mengadakan hubungan dalam lalu lintas sosial akan selalu beritikad baik, juga akan bertingkah laku penuh kehati-hatian sehingga tidak menimbulkan kerugian yang tidak perlu. ${ }^{49}$ Oleh karena itu jika terlanjur terjadi suatu sengketa dan perselisihan maka hendaknya selesai dengan kepuasan dan keadilan bagi para pihak, setidaknya diterima oleh para pihak. Salah satu upaya untuk menegakkan hukum dan memperoleh kepastian itu ada di upaya-upaya penyelesaian alternatif di luar pengadilan. Dalam konteks pembangunan ekonomi maka kepastian hukum dalam penyelesaian sengketa di segmen kompetisi sepak bola profesional sangatlah penting karena kepastian hukum dan sarana penyelesaian sengketa yang jelas akan membuat kompetisi menjadi kondusif dan memancing investor untuk tertarik dan bergabung. Karena kini sepak bola sudah menjadi kegiatan ekonomi, bisnis dan industri dengan skala global.

Perkembangan globalisasi saat ini telah membawa bangsa Indonesia dalam free market dan free competition. Untuk menyehatkan dan melancarkannya maka bangsa-bangsa di dunia menyusun multinational agreement dengan tujuan mewujudkan ekonomi yang mampu mendukungnya. Dengan adanya perkembangan ekonomi dan bisnis, maka tidak mungkin dihindari adanya sengketa (dispute) antar pihak yang terlibat. Adanya sengketa ini dapat berimbas pada pembangunan ekonomi yang tidak efisien, penurunan produktivitas, kemandulan dunia bisnis. ${ }^{50}$ Persepsi para pelaku bisnis sangat dipengaruhi oleh kondusifitas, oleh karena itu terbentuknya badan penyelesaian sengketa akan membuat para investor memiliki kepercayaan untuk terlibat dalam bisnis sepak bola di Indonesia karena sengketa antara pemain

\footnotetext{
46 Yudha Bhakti Ardiwisastra, Imunitas Kedaulatan Negara di Forum Pengadilan Asing (Bandung: Alumni, 1999), hlm.16.

47 Jum Anggraini, Hukum Administrasi Negara (Bandung: Graha Ilmu, 2012) hlm. 41.

48 HP Panggabean, Negosiasi (Jakarta: Jala Permata Aksara, 2017) hlm.5.

49 Ibid.

50 Frans Hendra Winarta, Hukum Penyelesaian Sengketa (Jakarta: Sinar Grafika, 2011) hlm. 1.
} 
dan klub akan lebih mendapat kepastian untuk dituntaskan.

\section{Urgensi Pembentukan Lembaga Peradilan khusus Sengketa Sepak Bola}

Teori pluralisme hukum mengenal apa yang dinamakan sistem hukum transnasional selain sistem hukum nasional dan internasional. Sistem hukum transnasional yang dijadikan pedoman oleh komunitas-komunitas di dunia ternyata sesuai dengan sistem hukum olah raga yang diterapkan oleh federasi-federasi olah raga internasional untuk menjalankan kegiatannya. Termasuk penyelenggaraan kompetisi sepak bola profesional yang dikendalikan oleh sistem hukum yang dibentuk FIFA. ${ }^{51}$ Namun dalam pelaksanaannya ternyata sistem hukum transnasional ini memiliki persinggungan dengan sistem hukum nasional yang berlaku. Dalam kondisi ideal, kedua sistem ini seharusnya saling dukung dan melengkapi. Terlebih negara dan FIFA sebenarnya memiliki tujuan yang sama dalam konteks memajukan dan meningkatkan kesejahteraan. ${ }^{52}$

Dalam konteks saling melengkapi itulah maka diperlukan suatu lembaga arbitrase yang khusus menyelesaikan sengketa antara pemain profesional dan klub sepak bola yang mendapat legitimasi dari negara maupun FIFA dan Federasi. Dari sisi komunitas sepak bola, FIFA dan PSSI jelas menghendaki lembaga tersebut, bahkan tahun 2017 lalu FIFA telah memberikan dana sebesar 40.000 dollar AS (sekitar Rp 532 juta) kepada PSSI. ${ }^{53}$ Dana tersebut untuk membantu PSSI membentuk pengadilan arbitrase independen guna menangani sengketa yang membelit klub dan pemain atau National Dispute Resolution Chamber (NDRC). ${ }^{54}$

Sementara dari sisi negara, keberadaan NDRC tersebut tak bertentangan dengan hukum nasional bahkan memiliki legitimasi berdasarkan Undang-Undang Nomor 30 Tahun 1999 Tentang Arbitrase dan Alternatif Penyelesaian Sengketa (UUAAPS).

Masyarakat dan komunitas memiliki karakteristik yang khas dan otonom dan belum tentu dipahami oleh pihak lain termasuk pemerintah dan organisasi di luar organisasi mereka. Sehingga pembentukan NDRC sangat penting dan mendesak, agar kasus-kasus dapat ditangani oleh mereka yang memahami persoalan dan ditangani oleh perwakilanperwakilan stakeholders yang selama ini terlibat dalam aktivitas sepak bola seperti perwakilan asosiasi pemain misalnya. Kehadiran NDRC ini pun tak melanggar hukum nasional dan kedaulatan negara, bahkan melengkapi dan mendukung kepastian hukum serta perlindungan terhadap hak asasi manusia.

51 Hinca IP Pandjaitan, Kedaulatan Negara VS Kedaulatan FIFA (Jakarta: PT Gramedia Pustaka Utama, 2011), hlm. 210-216.

52 Eko Noer Kristiyanto, "Negara Tanpa Sepak Bola”, Harian Umum Pikiran Rakyat, Bandung 4 Juni 2015.

53 Ferril Dennys, "FIFA Beri Dana Rp 532 Juta Untuk PSSI", Kompas.Com, http://ekonomi.kompas.com/ read/2017/02/10/21245988/fifa.beri.dana.rp.532.juta.untuk.pssi., diakses pada 11 Januari 2018.

54 NDRC, yang bertindak berdasarkan aduan, merupakan pengadilan arbitrase independen yang berada dalam naungan PSSI. Ada tiga substansi sengketa yang dapat diselesaikan di badan ini, yaitu terkait kontrak pemain di klub, kompensasi latihan (training compensation) atau kompensasi yang diberikan klub ketika mengikat kontrak pemain secara profesional kepada klub, di mana pesepak bola dilatih saat masih berstatus amatir pada usia muda, serta kompensasi solidaritas yaitu mekanisme penghargaan transfer antarklub. 


\section{Penutup}

Dalam konteks pembangunan ekonomi nasional. Pembentukan NDRC sebagai lembaga khusus yang menangani penyelesaian sengketa antara pemain sepak bola profesional dan klub sepak bola profesional mendesak untuk segera direalisasikan. Hal ini penting sebagai upaya penegakan hukum serta menjamin adanya kepastian hukum di negara ini yang diupayakan di berbagai aspek termasuk olah raga khususnya sepak bola. Kepastian hukum ini akan menciptakan situasi kondusif bagi kompetisi sepak bola profesional di Indonesia yang pada akhirnya akan menarik investor dan para pelaku bisnis. Dampak ekonomi dari kompetisi sepak bola profesional ini akan mendukung pemajuan kesejahteraan umum yang menjadi esensi dari pembangunan ekonomi nasional.

\section{Daftar Pustaka}

\section{Buku}

Anggriani, Jum, Hukum Administrasi Negara, (Yogyakarta: Graha Ilmu, 2012).

Ardiwisastra, Yudha Bhakti, Imunitas Kedaulatan Negara di Forum Pengadilan Asing,

(Bandung: Alumni, 1999).

Asshiddiqie, Jimly, Kemerdekaan Berserikat Pembubaran Partai Politik dan Mahkamah Konstitusi (Jakarta: Konstitusi Press, 2005).

Goodin Robert R, Responsibility Right \& Welfare, The Theory of the Welfare State (Colorado: Westview Press, 1988).

Kristiyanto, Eko Noer, Peranan Kemenkumham RI Dalam Penyelenggaraan Kompetisi Sepak Bola Profesional di Indonesia (Jakarta: Balitbang Hukum dan HAM RI, 2017).

Latip, Yansen Darmanto, Pilihan Hukum dan Pilihan Forum Dalam Kontrak Internasional (Jakarta: UI, 2002).

Marzuki, Peter Mahmud, Penelitian Hukum (Jakarta: Kencana, 2010).

Muhammad, Rusli, Kemandirian Pengadilan Indonesia (Yogyakarta: FH UII Press, 2009).
Pandjaitan, Hinca IP, Kedaulatan Negara VS Kedaulatan FIFA, (Jakarta: PT Gramedia Pustaka Utama, 2011).

HP, Panggabean, Negosiasi, (Jakarta: Jala Permata Aksara, 2017).

Soekanto, Soerjono dan Sri Mamudji, Penelitian Hukum Normatif: Suatu Tinjauan Singkat (Jakarta: Raja Grafindo Persada, 2001).

Surbakti, Ramlan, Memahami Ilmu Politik (Jakarta: PT Gramedia Widiasarana Indonesia, 2015).

Usman, Rachmadi, Pilihan Penyelesaian Sengketa di Luar Pengadilan (Bandung: PT

Citra Aditya Bakti, 2013).

Winarta, Frans Hendra, Hukum Penyelesaian Sengketa (Jakarta: Sinar Grafika, 2011).

Yamin, Muhammad, Naskah Persiapan UndangUndang Dasar Negara Republik Tahun 1945 (Jakarta: Jajasan Prapantja, 1960).

\section{Makalah/Artikel/Prosiding/Hasil Penelitian}

Kristiyanto, Agus, "Penguatan Kebijakan Publik Usaha Pengentasan Kemiskinan Melalui Pengembangan Industri Mikro Olah Raga", Jurnal Ekonomi Pembangunan Volume 12, Nomor 2 (2011)

Kristiyanto, Eko Noer, "Negara Tanpa Sepak Bola", (opini dimuat dalam Harian Umum Pikiran Rakyat, Bandung 4 Juni 2015).

Kristiyanto, Eko Noer, "Sepak Bola dan Kesejahteraan Umum", (opini dimuat dalam Harian Umum Tribun Jabar, 20 Agustus 2015).

Kristiyanto, Eko Noer, Implementasi Peraturan Menteri Dalam Negeri Nomor 13 Tahun 2006 Tentang Pedoman Pengelolaan Keuangan Daerah Dalam Pengalokasian Dana APBD Kepada Klub Sepak Bola Peserta Liga Indonesia, (Bandung: UNPAD, 2008)

Rajagukguk, Erman, "Peranan Hukum di Indonesia: Menjaga Persatuan, Memulihkan Ekonomi dan Memperluas Kesejahteraan Sosial", (makalah disampaikan dalam rangka Dies Natalies dan Peringatan Tahun Emas Universitas Indonesia, Jakarta, 2000)

Foster, Ken, "Is There a Global Sports Law?", Entertaintment Law, vol.2 No.1, London (2003).

Manan Bagir, "Penelitian Terapan di Bidang Hukum", (makalah disampaikan pada Lokakarya Peranan Naskah Akademis Dalam Penyusunan Peraturan Perundang-undangan, BPHN, Jakarta, $9-11$ November 1993). 
Violetta Simatupang, "Pariwisata Olah Raga", (opini disampaikan dalam Harian Umum Pikiran Rakyat Bandung, 2016).

\section{Internet}

Donny Afroni, "Bambang Pamungkas dan Leo Saputra Gugat Persija Jakarta", Goal, http://www.goal.com/id/news/1387/ nasional/2013/11/19/4418163/bambangpamungkas-leo-saputra-gugat-persija-jakarta, (diakses 11 Januari 2018)

Gonsaga Aloysius, "Kasus Bepe Momentum Pembenahan", Kompas.com, http://bola. kompas.com/read/2013/12/19/0603081/Kasus. Bepe.Momen.Pembenahan, (diakses 11 Januari 2018)

Kristiyanto, Eko Noer, "Bambang Pamungkas dan Bobotoh", www.pikiran-rakyat.com, http:// www.pikiran-rakyat.com/kolom/2017/10/29/ b a m bang - pamungkas - dan-bobotoh persib-412469, (diakses 11 Januari 2018)

Kristiyanto, Eko Noer, "PSSI dan Organ Yudisialnya", www.Pikiran-Rakyat.com http://www.pikiranrakyat.com/kolom/2017/08/13/pssi-dan-organyudisialnya-407254, (diakses 11 Januari 2018)

Nyon, "Klub Tak Bayar Gaji Pemain Ada Juga di Eropa", detikSport, https://sport.detik.com/ sepakbola/bola-dunia/2296988/klub-tak-bayargaji-pemain-juga-ada-di-eropa , (diakses 11 Januari 2018)

PSSI, "Hasil Pertemuan FIFA dengan PSSI Terkait NDRC, www.pssi.org, http://www.pssi.org/ news/hasil-pertemuan-fifa-dengan-pssi-terkaitndrc (diakses 11 Januari 2018).

Utama Satria Sakti, "Sengketa Sepak Bola Kini Ditangani NRDC", Media Indonesia online, http://www.mediaindonesia.com/news/ $\mathrm{read} / 140721 / \mathrm{sengketa-sepak-bola-kini-}$ ditangani-ndrc/2018-01-15, (diakses 15 Februari 2018).

Wibowo Agung Putranto, "Penyelesaian Sengketa Kontrak Pemain: Kewenangan Para Pihak", Kumparan, https://kumparan.com/agungputranto-wibowo/penyelesaian-sengketakontrak-pemain-kewenangan-para-pihak, (diakses 11 Januari 2018)

\section{Peraturan}

Undang-Undang Dasar Negara Republik Indonesia Tahun 1945

Undang-Undang Nomor 30 Tahun 1999 Tentang Arbitrase dan Alternatif Penyelesaian Sengketa Statuta FIFA 